\title{
SOCIAL MEDICINE IN BRAZIL: AN ALLIANCE BETWEEN SANITARY EDUCATION AND POPULAR PEDAGOGY
} MEDICINA SOCIAL NO BRASIL: UMA ALIANÇA ENTRE EDUCAÇÃO SANITÁRIA E PEDAGOGIA POPULAR

\author{
Ricardo Abussafy de Souza and Sonia Aparecida Moreira França \\ “Julio de Mesquita Filho" São Paulo State University, Assis/SP, Brazil
}

\begin{abstract}
This study unfolds from the analysis of a set of documents collected during my doctoral research, which investigated the management of filth and its relationship with the governing of populations during the formation and development of modern cities. In this set, annals of Brazilian hygiene congresses, conducted during the first half of the twentieth century, a period characterized by the enlargement of techniques and practices of social medicine, were selected. Such annals of congresses and some laws of the time evidence the construction of an alliance between Sanitary Education and techniques of popular pedagogy, responsible for the population adherence to standards of conducts countersigned in social hygiene requirements. From Michel Foucault's writings on genealogical analysis, descent lines are described about healthy modes of conduct which, in turn, produce some effects in contemporary truth about personal and social hygiene.
\end{abstract}

Keywords: social medicine; sanitary education; popular pedagogy; genealogy.

\section{RESUMO}

Este estudo é desdobramento da análise de um conjunto de documentos coletados durante minha pesquisa de doutorado, em que se investigou sobre a gestão das imundícies e sua relação com o governo das populações durante a formação e desenvolvimento das cidades modernas. Neste conjunto, foram selecionados anais de congressos brasileiros de higiene, realizados durante a primeira metade do século XX, período caracterizado pela ampliação de técnicas e práticas de medicina social. Estes anais de congressos e algumas legislações da época evidenciam a construção de uma aliança entre Educação Sanitária e técnicas da pedagogia popular, responsáveis pela adesão da população a padrões de condutas referendadas em preceitos de higiene social. A partir dos escritos sobre análise genealógica de Michel Foucault, descrevem-se linhas de proveniências sobre os modos de conduta saudáveis e que, por sua vez, produzem na contemporaneidade alguns efeitos de verdade sobre higiene individual e social.

Palavras-chave: medicina social; educação sanitária; pedagogia popular; genealogia.

\section{Introduction}

Concomitantly with the emergence of modern cities, there is the production and accumulation of filth as an issue to the governing of population agglomerates, and in this context, Sanitary Education would function as an educational tool for the construction of another mode of conduct. This study aims to analyze the processes through which it is shown a kind of governing of conducts ruled by the precepts of social medicine as a device of popular participation to the effectuation of a series of social hygiene practices.

This discussion finds its relevance when countering some contemporary studies that claim that practices of health allied to techniques of popular education derive from "social movements of popular character ... from the 1960s, with support organizations to popular struggles, especially the peasant struggle, experiences that coincided with proposals based on the principles of Community Medicine" (David \& Acioli, 2010, p.128).

In contrast, the documents hereby analyzed demonstrate that this alliance between Sanitary Education and pedagogies of popular participation finds its descent in social medicine and in hygienist reform from the first half of the twentieth century. This period was characterized by the expansion of social hygiene techniques and was widely discussed in Brazilian hygiene congresses as it is demonstrated 
in Renovato and Bagnato's study (2011) about Sanitary education in São Paulo health centers (1925-1930): practices and subjects $[$ A educação sanitária nos centros de saúde de São Paulo (19251930): práticas e sujeitos]. This historiographical recovery of articulations made at the hygiene congresses of that period raise the reconfiguration of hygiene strategies to operate outside medical clinics and highlights the importance of popular strategies of inclusion of social medical knowledge in townspeople's daily habits.

A description of practices to be here presented, among others that regard procedures and mechanisms of the governing of human conducts by means of techniques of filth management, is the object of analysis in the doctoral research conducted since 2009 and scheduled for completion in March 2013.

Methods of filth management become the object of public life and therefore subject to a reason of State. The accumulation, storage, movement and disposal of excrescences, excess, obsolescence and putrefactions of the city have as a point of intersection the production of their confinement, isolation and invisibility. Therefore, it is transmuted into one of the unbearable experiences of urban spaces, as well as death, disease, misery, madness and sedition. Thus, the incessant appearance of technologies for dirt organization, resulting from the processes of migration of people to urban life, is revealed as one of the main fields of questioning the experiences of governmentality.

The concept of governmentality directs the present discussion to the analysis of the practices of the government of self and others in the ensemble formed by institutions, procedures, rationales and tactics that, in a way, organize the population agglomerates as a manifestation and object of the power of Modern State. Michel Foucault was devoted to the description and analysis of devices and practices of this subjectpower relation in a set of lectures at the Collège de France, mainly between the years 1975-1980: Il faut la société déféndre (1975-1976), Sécurité, territoire et population (1977-1978), Naissance de la biopolitique (1978-1979), Du governement des vivants (1979-1980) (Castro, 2009, pp.188-192).

Besides the procedures of the governing of others, practices of the government of self developed by social-medical and hygienist knowledge are evinced. As one of the main vectors of spread of this new épisteme of urban life, sanitary education consolidates some of these techniques of government upon self for the salvation of an artificial soul, not the soul of every human being anymore, but the soul of the city.
Regarding the waste management practices, the prominence of certain rules of human conduct, from such practices of subjectification, subscribes to the city habits of promotion of personal hygiene and public health. By launching in history such contemporary effects, this theme provides the conditions for a diagnosis of present time.

\section{Methodology}

The following methodological proposition has as guiding principle a research on the descent (Herkunft) of human conduct formation in the context of social medicine, based on specifics of the Brazilian scenario. This precept, the study of the descent, relies on discussions promoted by Michel Foucault (2004a) on the genealogical strategy as research methodology. In the article Nietzsche, genealogy and history (Nietzsche, a genealogia e a história), the study of descent appears as a historical conception of genealogical research, which analyzes not an unequivocal and continuous source, but highlights the "complex course" of historical truths. Its construction, its heritage, not from a natural and original truth, but the heritage from heterogeneous articulations, often contradictory, full of fissures and faults (Foucault, 2004a, pp. 20-22). In this study particularly, an assumption made by Foucault is central: "genealogy is gray; it is meticulous and patiently documental. It works with parchments that are scrambled, scratched, rewritten several times" (Foucault, 2004a, p.15). While researching on the descent of social hygiene inscribed in contemporary lifestyles, it was necessary to scrutinize the documents that assert on the construction of such rules of conduct, even if sometimes it seems not to make direct reference to the subject's conduct, but it is located in discourses and practices inscribed in the exteriority of the subject (Foucault, 2004a, p. 21).

Thus, the documents of Brazilian hygiene congresses, formed by doctors and public managers in the sanitarian field, appear as consistent conductor of analysis, in addition to other documents such as a law on the establishment of garbage tax (1917) and a project to the removal of garbage in the city of Rio de Janeiro (1901).

Among the researched congresses, the first (1923), themed on the Remodeling of the cities (Remodelação das cidades), and the seventh congress (1943), themed on Sanitary Education (Educação Sanitária), assemble the two main axes for social medicine subsequent analysis, that is, the city and the body. The city, for the modes of conduct occur in 
the relations in society, or, more effectively, relations as historical marks of humanity. The body, for it is characterized in Foucault's words as "the surface of inscription of events", that is, "the body - and all that relates to the body, diet, climate, soil - is the place of Herkunft" (Foucault, 2004a, p. 22).

\section{Urban putrescence: the construction of an unbearable}

In Brazil, in early experiences of emergence and expansion of the modern city, the urban agglomeration built fainter levels of supportability in social life. Carcasses and animal bones, food scraps, household rags and junk became increasingly present and unpleasant to the habits of the new urban organization.

In Rio de Janeiro, as it is known, it is enough an hour of sun, it is enough just an hour, to take organic matter to putrefy and create with all the elements that provide plenty of room for it, a big, immense pond of microbes, that keeps itself constant over our poor city the reputation for unhealthiness the main cause of our delays and mistrust with which our future is looked upon [sic]. (Pinto, 1901, s.p.).

"In Europe, Brazil is Rio de Janeiro" - in this manner, Antônio José Pinto (1901) intends to warn "Lord Mayor" ("Senhor Prefeito") about the problems in removing the garbage from the once Federal Capital. His concerns in attracting investments and foreign immigrants motivate him to submit to the municipal power a Project of Waste Removal:

Your Excellency knows about the bad impression that the lack of cleanliness of this important capital leaves on everyone, and especially about the impression that in all foreign countries has produced, a sad reputation of unhealthy which Rio de Janeiro has acquired, and that naturally, it is not. (Pinto, 1901, s.p.)

Among the most acute problems there are some vices of residents who fail to deliver the garbage, "in the unspeakable interest of using it as manure for gardens or orchards", or that by "negligence accumulate trash without knowing or without regard to the evil that may result from it" (Pinto, 1901, s.p.). It is evident by these reports that the need for urban health begins to curtail domestic practices such as the very garden fertilization. Obviously, the need for the removal of excrement and waste is present in modern cities as a result of maintenance required, because:

in violation of the standards of cleanliness it is perceived the same contempt for collective places. In records of the Assembly of Salvador, for example, complaints against landlords who threw all sorts of waste on the streets are repeated throughout the XVII and XVIII centuries. Even in the nineteenth century the postures of the Assembly tried, in vain, to regulate the dumping of garbage and other debris on public roads. The street was considered the boundary of the house, as the slave quarters was the ejectment room of the big house. The rural landowners modeled the city following the example of the plantation or the farm. (Costa, 2004, p. 38)

The garbage relation with the aversion to the malodorous manifests is also observed in reports on the work of carters. The carters often appear in the file of documents belonging to the Historical Archives of Rio de Janeiro. They were self-employed or employees responsible for collecting household waste in the city and that, therefore, needed to acquire a work permit by the City Hall. Their carts, "as fetid as the content they carry," is another critical point of urban sanitation services, which worsens with the lack of accuracy regarding the time of collection, and the known defect of residents in reusing organic matter like compost (Pinto, 1901).

It casts on the indecency of the practice of removing the trash during the day, which forces townspeople to live with such consternation: "for years distinct hygienists, press, and everybody have complained that the trash removal should be during the night; but neither violating the domicile nor individual guarantees with vexatious measures [sic]" (Pinto, 1901, s.p.).

Ever since the arrival of the royal family in 1808 in the city of Rio de Janeiro, the sanitary issue was the target of the first urban reforms. Luis Antonio Baptista narrates such changes through the eyes of the black Muane, a slave of a bourgeois family, who would have as one of her tasks, emptying the latrines from the house of her masters at sea. Muane perceives the changes of the cities:

The weight of the tub left her dizzy. It was hot that night in March in the city of Rio de Janeiro. Removing the sweat that fell over her eyes, she could see far away, in the bay, something strange. Tired of unloading on the beach so much smelly stuff, still, she could see a large number of boats. The stench no longer bothered her so much, but the body felt the marks of hygiene that the house of the lord demanded (Baptista, 1999, p. 52).

The slaves responsible for this task were called Tigers (Tigres) because the shit that dripped from the buckets striped their black skin, giving them this despicable appearance. It adds to such a nickname, the fact that the passersby got away from these characters 
on the streets, as if they were running from a fierce tiger. These tasks were used as punishment by their masters, which would eventually isolate them from the other townspeople and even from their fellow slaves, because of the unbearable stench that accompanied them (Souza, 2007, pp. 55-68).

The changes announced by the arrival of the court would bring a revolution to the city that, until then, did not see the hygiene habits as a crucial problem, and even the lack of hygiene that the colonists would, from then on, shout throughout the city.

In the early nineteenth century, European settlers brought from overseas the good news to the barbarians: "The city was changing and that people needed to keep up with the new soul of Rio de Janeiro, said the new owners full of ruffles with their faces of church angel" (Baptista, 1999, p. 57). This new soul of the city advocated the precepts of social welfare and the sacrifices that each townsman would have to do to comply with the salvation of the urban environment.

Throughout thisperiod, it is possibletoobservethis intrinsic relationship between imported technologies from the old world to the waste management and, and consequently, to the urban reform. With the arrival of the Portuguese nobles to turn Brazil into the new Lusitanian empire, crucial changes would be noticed, which after a hundred years, would culminate in the Oswaldo Cruz's sanitarian reforms and in the Vaccine Revolt (Revolta da Vacina ).

Houses with larger windows, enlargement of streets, a brighter city and a whole repertoire of new guidelines were needed so that the nobility could occupy the town. The locals were not seen as a danger anymore, but as dirty and exotic, which with good cleaning, would solve the issue: "The owners' dirt and the presence of blacks in the streets made those people turn up their noses" (Baptista, 1999, p. 57).

In this context, some hygienic practices prescribed by the discourse of social medicine at the time, would have crucial influence on the transformation of Brazilian cities, for the management of its excrescences, and therefore, for the change of conduct.

\section{Social-medicine: the body as an extension of the urbs}

Reading the Annals of the City Council of São Paulo, regarding the years 1906 and 1912, one finds some reports about the cleaning of the city. One of the most controversial guidelines concerned the implementation of a new tax on trash. These debates often enumerated the advantages and disadvantages of this sanitary tax as well as questioned the legitimacy of the City Council to legislate on the creation of this new municipal tax.

Councilman at the time Alcântara Machado (1918) propounds a bill for the creation of a fee that would cover the production of household waste in the municipality. Such proposition discourses on the City Problems (Problemas Municipaes) suffered by the capital of São Paulo amid its cosmopolitan boiling:

The street is the city hygienic unit. The urbs is worth salubrity, and so are the streets that constitute it. As the cleanliness of the body is the foundation of all individual hygiene, it is also true that cleaning the public highway is the pivot of the whole urban hygiene. (Machado, 1918, p. 59)

This axiom of public cleaning appears as an area of analysis for the description of some processes by which body and street become products of hygiene practices, at the very moment of the development of modern cities.

These two physical units, body and street, appear as objects of hygienic practices, in order to expunge them all the dirt and, in its place, bring to Brazilian cities the good news of the modern world. To each of these units it is combined two concepts that refer to a modern mode of intelligibility: to the body, it is presented the individual, an indivisible political unity of state and object of government of privacy; to the $u r b s$, it is presented the street as their value unit and therefore its object of intervention for the governmentality of public space. Two different intervention spaces that, when Alcântara Machado places them in a new plan of existence, have their walls demolished by the need of hygienic organization aiming social welfare maintenance.

Registering the body in the field of the individual would be precisely this act of breaking the physical limit and releasing it as a political unity belonging to the urbs. Hence there are the body and the street as elements of a proportionate reason entered into this new discursive and practical field called hygiene.

About such practices, Richard Sennett describes "a story of the city told through the bodily experience of the people" (1997, p. 15).

The revolution of Harvey favored expectations and changes of urban planning worldwide. His discoveries about blood circulation and respiration led to new ideas about public health. In the eighteenth century Enlightenment, they began to be applied to 
urban centers. Builders and reformers began to place greater emphasis on everything that facilitated people's freedom of transit and their oxygen consumption, imagining a city of continuous arteries and veins through which the inhabitants could be transported such as erythrocytes and leukocytes in healthy plasma. The medical revolution seemed to have operated the exchange of morality for health - and social engineers established the identity between health and transportation/circulation (Sennet, 1997, p. 214).

The health of a body, as a biological phenomenon, or rather biopolitical, offers new codes for management of this other political body, the city, in order to enter a new path to human happiness. In the sight of a functional and utilitarian modern science, the body acquires new textures and consistencies. This science, which relies on the ballast of social-medical knowledge, ultimately "leads our eyes to a world of constant visibility” (Foucault, 2008a, p. VIII).

In this new growing urbs, the soul is no longer the mainstay of man's salvation. The prayers and religious behaviors lose space for the technical and scientific procedures of body care, which is legitimized as the new paradigm in service to the welfare and human happiness: "health was seen, increasingly, as an individual responsibility rather than a godsend. The city that began to emerge in the eighteenth century would help to reproduce this paradigm in a context of healthy living" (Sennett, 1997, p. 218). The path to human salvation and happiness acquires materiality in the clean body and streets and no longer in the transcendental belief in the salvation of Christian souls.

Impregnated with such solidity and objectivity, this policy of bodies shows a route that elects community medicine as one of the pillars of ordering modern rationality and their urban agglomerates. From the descriptions of Michel Foucault (2004b , pp. 7998) on The birth of social medicine (Nascimento da Medicina Social) in the late eighteenth century and early nineteenth century, some practices have collective health as a device that operates certain power over the body: "The control of society on individuals ... begins in the body, with the body. It was in the biological, in the somatic, in the body that capitalist society primarily invested. The body is a bio-political reality. Medicine is a biopolitical strategy" (Foucault, 2004b, p. 80).

The stench and corruption caused not only by the excrement and the lack of hygiene of individuals but also by any form of putrid matter accumulated in public spaces, whether or not visible to the eye, call into question the very existence of the city. The malodorous products permeate the soil, the air, the food, and sicken bodies. The cemeteries, ossuaries and slaughterhouses become focus of miasmas. Food scraps, rags, dead animals and other organic and inorganic substances cannot accumulate in the spaces of the cities and, as well as subjected to a general health status, it is imperative to set them in movement, and in this case, away from urban spaces: "The invention of the urban issue", the triumph of functional design of the "citymachine' incite a 'topographical toilet', inseparable from the 'social toilet', that the cleaning of streets and installation of local confinement attest" (Corbin, 1987 , p. 119).

The putrefaction produced by human waste and garbage of this experience of population accumulation sounded the social medicine alert for the production of more permanent and broader personal hygiene and public health practices.

\section{Sanitary education as a source of popular pedagogy}

In the Annals of the VII Brazilian Congress of Hygiene (VII Congresso Brasileiro de Higiene), dated 1943, the scientific articles are presented as knowledge product of the experiences of urban sanitation held in Brazil since the turn of the twentieth century. In these records, the need arises to make the population, in general, be educated to produce aseptic individual and society. The theme of this event would then be Sanitary Education.

At that conference, Dr. Joaquim Bannitz Novaes (Director of the Section of Propaganda and Sanitary Education of the Department of Health of the State of São Paulo), in his lecture entitled Propaganda and Sanitary Education (Propaganda e Educação Sanitária), stated the importance of resorting to different processes other than the imposing devices of the legal apparatus:

'Education is better than legislation. If it is slower, however, it is safer'. This is because if legislation can only reach a relatively small number of cases, with constraints of space and time - and great expense of implementation and enforcement - propaganda and sanitary education, much easier to extend and intensify, finds practically no limits to its scope, both in surface and in depth. While consolidating already made gains, raising the collective consciousness, it realizes new achievements, a progression largely invisible, but always considerable. It is a kind of indirect action, but nevertheless strongly persuasive. (VII Congresso Brasileiro de Higiene, 1943, p. 32)

Under this reasoning, it is presented the considerable factors for this kind of social feasibility 
study of the production of health: the population scope, the time to obtain results; costs of law enforcement, surveillance, punishment, correction, and perhaps the most interesting, the concern that the strategy acts both on the surface and in the depths of man's life.

More than a dialectical relationship, there is a paradox. The modus operandi of this government strategy of human conduct is based on deeper action (or direct) the production of a "collective consciousness" that, in turn, is structured in social relations and not just in a psychological interiority of the subject. This means that the object of action on the conduct does not focus on the interiority, but on the externality of the subject.

This process of individuation that does not oppose the interest of the state to the individual, but rather inserts it in their operation, is translated into another assertion made by one of the participants of the mentioned Congress. Dr. Waldomiro de Oliveira (Director of Occupational Hygiene Session), in his lecture titled Sanitary Education in Social-Medical Cooperation (Educação Sanitária na Cooperação Médico-Social ), presented at first the prerogative to value Sanitary Education: "everyone wants health and long life" (VII Congresso Brasileiro de Higiene, 1943, p. 60). It is a desire inserted as an interest of each and everyone. Oliveira also replicates Bannitz's assertion - "education is better than legislation" (VII Congresso Brasileiro de Higiene, 1943, p. 64) - and argues about the importance of "sanitary awareness training" for not being "vulgarized" yet, and having its performance "limited to small groups". Therefore, there is the need to "win the required amplitude in popular classes" (VII Congresso Brasileiro de Higiene, 1943, p. 60).

The producing mechanism of this collective consciousness undergoes a process of producing desire for urban hygiene which must be carried by each townsman, for the insalubrity of few can influence the health of an entire agglomeration. This education procedure would then have to go beyond the walls of formal schools and find other more popular formation mechanisms.

In another text in the annals of this Congress, "Sanitary Education" ("Educação Sanitária"), Maria Junqueira (VII Congresso Brasileiro de Higiene, 1943), gives voice to the discourse of educational psychology, citing Noemy Rudolfer Silveira, one of the area authorities in the period: "Education is that process by which more experienced beings seek to guide the conduct of immature beings, or less experienced ones, so that desirable goals [our emphasis] become customary standards of conduct" (p. 117). The desire, not only an individual and personal one, but also a desire belonging to a rationality of State to be enrolled in human conduct, appears as the object of the games of interest between the individual and the population.

In the production of this paradox, between difference and normalization, it is found the desire, the governmentality gateway. A process that takes place on the surface of its relationships and that deepens in the intensity of the desire to the point of giving the impression that the choices are randomly made, but instead, they appear in a predicted set of possibilities. For this production of desire in the exteriority of a subject, Foucault says:

There is, according to the first theorists of the population in the eighteenth century, at least one variant that causes the population, taken as a whole, to have a motor of action, and only one. This motor of action is desire. ... Desire is what causes all individuals to act. ... The individual, moreover, may well be mistaken in his desire, as to his personal interest, but there is one thing that does not deceive: the spontaneous play or, at any rate, spontaneous and at the same time, regimented of the desire that will in fact allow the production of an interest, something that is interesting for its own population. Population of collective interest for the game of desire: that is what features at the same time the naturalness of the population and the artificiality of the possible created ways to manage it. (Foucault, 2008b, p. 95)

This promotion of health practices allied to participatory educational methods makes the individual, far from feeling subjugated, recognize him or herself in this standard operation designed by reason of State. Much more for strategic reasons than scientific or ideological grounds, producing a feeling of participation for the construction of this regulatory process is configured as a Sanitary Education intervention technique.

In line with such thinking, the most important issue from the participatory pedagogical point of view in Sanitary Education is thus presented by Junqueira: "is sanitary education synonymous for health education, or is sanitary education a learning process (of self preparation)? Teaching and learning are not the same. Learning occurs only through the efforts of the learner"(Nyswander, cited by VII Congresso Brasileiro de Higiene, 1943, p. 118).

Sanitary Education is configured, then, as an activity of learning and not of teaching, and so outlined, the effort and participation of the individual are primary to pedagogical success. According to Foucault (1995, p. 242) "power only exists in act" and its exercise is effective in an action that is directed to another action. 
The operation of power relations, of course, is not an exclusive use of violence more than the acquisition of consent; ... It is a set of actions on possible actions; it operates in the field of possibility in which the behavior of active subjects is fit; it incites, induces, diverts, makes it easy or more difficult, extends or limits, makes it more or less presumable; in the edge, it coerces or completely prevents, but it is always a way to act on one or more active subjects, and how much they act or are likely to act. (Foucault, 1995, p. 243)

Considering the action and not the obedience as ballast to certain normative sieve involves calculating the extent of the field of possible actions, and for that to happen, it is necessary to encourage the idea of freedom to understand the actions and reactions, ways of adherence and resistance, the effects and responses. In this sense, Foucault continues to describe the relationship between the subject and the forms of power: "The exercise of power consists in 'driving conducts' and in ordering probability. The power, actually, is less the order of confrontation between two adversaries, or a bond with respect to each other, than the order of 'government"' (Foucault, 1995, p. 244).

In this way, Junqueira's speech at the VII Brazilian Congress of Hygiene (VII Congresso Brasileiro de Higiene) points to the "opportunities for action" for the educator that is not restricted to the interiors of traditional schools. More than that, by being asserted as an educational process of popular character, they permeate in countless formative experiences of human conduct. Their field of expertise is multiplied in different groups of learners as

practical courses of prenuptial, pre-natal care, child
care, epidemiology, nursing home, home economics,
home educational action hygiene ... "centers for
mothers", "center for brides", "centers for children and
youth", "center for delinquents", whose essentially
practical programs develop around the issue of health.
(1943, p. 122)

This popular pedagogy of Sanitary Education then emerges as a field of consensus on several papers presented by scientists who lectured at the XII Brazilian Congress of Hygiene (XII Congresso Brasileiro de Higiene). An assistant of the Faculdade de Higiene e Saúde Pública (Hygiene and Public Health College), Costa Sobrinho, says that the educator would be responsible for contacting the learner's interest, and also aims at including the "marginal populations" in this process (VII Congresso Brasileiro de Higiene, 1943, p. 95). Jandyr Maya Faillace (Professor of Hygiene and General Director of the State Department of Health of Rio Grande do Sul) and
Pedro de Medeiros Mitchell (graduate Sanitarian from the Course of Public Health and Medical Inspector of D. E. S. of Rio Grande do Sul), in joint lecture, point to the necessity of using alternative means such as cinema, newspapers, advertisements and other "national complements" to reproduce scenes involving the theme of "popular sanitary education" and the establishment of standards of sanitary education of popular nature (VII Congresso Brasileiro de Higiene, 1943, p. 45). Waldomiro de Oliveira (Director of the Department of Occupational Hygiene), in his lecture "Sanitary Education in Social-Medical Cooperation" ("Educação Sanitária na cooperação Médico-Social”) warns that sanitary education would only get more effective results if guided by the experience with small groups, and would win "the necessary extent in popular classes" to achieve "sanitary education of the masses" (VII Congresso Brasileiro de Higiene, 1943 , pp. 60, 63). For, as sanitarian Dr. Guarany José de Souza complements in his lecture "The importance of health education in public health" ("A importância da educação sanitária em saúde pública"), "education of the people in the principles of healthy living and disease prevention is the most important function of the Departments of Health" (VII Congresso Brasileiro de Higiene, 1943, p. 113).

Thus, it is delineated a "popular pedagogy of personal hygiene" (Corbin, 1987, p. 98), in which the production of a sanitary awareness grows no more bycompliance, but by an internalization of content constituting the normative field that would institute a desire to asepsis. Only this way, the citizen would be mobilized to change their habits according to the precepts of hygiene in adherence to a proposed public health.

\section{"Man is not born human"}

From these definitions, in which it is necessary the diffusion of the hygienist knowledge of popular layers from their consent, or rather, their participation and action on their own behavior, it is evidenced a definitive concept of Sanitary Education proposed by Junqueira: "it is the process by which, under planned influences, habits and consciences are created in order to obtain, for human beings, health at birth and good conditions for their defense and their improvement" (VII Congresso Brasileiro de Higiene, 1943, p. 118).

In another article, J. da Costa Sobrinho, discussing the importance of Sanitary Education for the development of urban life, also presents his platform for improving the human species. On these considerations, the author is devoted almost entirely 
to the production of patterns of healthy habits and manner, where education will serve to intervene in the "natural formation of man," since only the production of such parameters would enable "living well in group and in society" (VII Congresso Brasileiro de Higiene, 1943, p. 92).

More than just intervening in the improvement of the human being, education produces the very condition of mankind: “'man is not born human'. It becomes human, however, from birth, undergoing a continuous process of conditioning and reconditioning at home, at school and in society, until acquiring the characteristics of a human being"; and adds: "man must be educated, to be useful to themselves and to society" (VII Congresso Brasileiro de Higiene, 1943, p. 92).

These physicians of the city are revealed as new artificers, health artificers, because they know the laws that govern nature and produce artificial techniques to form the great work of modern civilization: urban life. As Dr. Armando Godoy states, this fact provides hygienists to "replace the actual laws by artificial ones" (1923, p. 39). To such city phenomenon, it is added, as effects of these urban agglomerates, the production of existence artifices to things and men.

The use and effects of these artificial laws for intervention and transformation of nature were also objects of the Political Philosophy of this period of the Modern State formation. Thomas Hobbes (1997), in the seventeenth century, observed the problems of cities when publishing his most famous work Leviathan or The Matter, Form and Power of a Common Wealth Ecclesiasticall and Civil (Leviatã ou matéria, forma e poder de um estado eclesiástico e civil), whose first argument is precisely this human faculty of creating artificial life.

Just as so many other things, nature (the art through which God made and governs the world) is imitated by the art of man in this as well: that it is possible to make an artificial animal. ... And art goes even further, imitating that rational creature, the most excellent work of nature, Man. For by art is created that great Leviathan called a State or City (in Latin Civitas), which is but an artificial man, though of greater stature and strength than the natural man, for whom protection and defense it was designed. And in which the sovereignty is an artificial soul, since it gives life and motion to the whole body; Salus Populi (people's safety) is its purpose. (Hobbes, 1997, p. 27)

The city, as an artificial creation of human life, generates an entire complex of relations, whose pacts and conventions generate this "Political Body" (Hobbes, 1997), habitat of popular agglomerations.
Salus Populi is its purpose, the health of a people, which does not mean specifically the health of each and every one, but of this "artificial man". It is thus established this art of governing life, no longer just for the sake of itself, but to benefit the health of public life.

Proceeding on these considerations, Costa Sobrinho indicates the common denominator or the scale that indicates these cultural indices expressed in human habits and behavior: "the sick man is not just dead weight, but an embarrassment to his family and a burden to society. Man should strive to stay healthy in order to be always useful to his fellows" (VII Congresso Brasileiro de Higiene, 1943, p. 92).

The design of a healthy human being is submitted to the conception of a productive society in which its opposite would represent a burden not only for oneself but also for everyone; and if one is an embarrassment and burden to society, everyone has the right to demand one's health and usefulness. In this sense, the inhabitant of the city has the right to intervene in the habits of every citizen on behalf of a productive society and its progress and happiness.

The formation of this rationality is produced from healthy practices that claim for themselves the way for the improvement, not only of the individual, but also of its kind. According to Costa Sobrinho, the promise of a human happiness that conveys "understanding, order, safety, comfort and cultural progress" (VII Congresso Brasileiro de Higiene, 1943, p. 92). The author also finds support in the decisions of the World Health Organization (WHO) that consider health as the first of the "fundamental principles for achieving "happiness for all peoples, for the harmony of their relationship, and for their safety" (VII Congresso Brasileiro de Higiene, 1943, p. 92).

Happiness becomes a clever method of employing a set of emotions to guide and focus attention on the practices of Sanitary Education. Happiness is therefore the expression that takes place in the development of a biopolitical personality and that elects as field of activity the "human individuality, useful for itself, and able to cooperate for the improvement of society, culture and progress of people's happiness" (VII Congresso Brasileiro de Higiene, 1943, p. 95).

This is because, for this proposition, changing a consciousness way of being for the development of the human species, occurs from the ways of being of an organism. However, their results are not perceived in the individual. On the contrary, as Maria Junqueira states, "the action of each cycle will not result in perfection, but in the progressive improvement by replacing each generation for a healthier one. The 
concept that education must begin years before the individual is born has hereby its explanation" (VII Congresso Brasileiro de Higiene, 1943, p. 119).

In this sense, Costa Sobrinho alerts to the fact that for the "protection of man as a member of society", it is necessary reconditioning their habits and manners, "in order to make them able to be interested and to cooperate with this important social work which seeks health or even human happiness" (VII Congresso Brasileiro de Higiene, 1943, p. 94).

Waldomiro de Oliveira asserts that "the formation of healthy habits defends the individual and collaborates with the protection of the species" (VII Congresso Brasileiro de Higiene, 1943, p. 62). Thereby, social, moral and economic conditions shall be subjected to medical selection from biological indices. For the author, public health is a social and economic issue, and he claims "without fear of error that social facts are always, and increasingly, biosocial" (VII Congresso Brasileiro de Higiene, 1943, p. 64).

\section{Discussion}

These reports present a diagrammatic analysis of some mechanisms of population management in the context of modern cities, whose effects occur in human relationships and, consequently, in the production of lifestyles. This diagram is configured in three main lines responsible for leading such relations: (a) alliance between biological knowledge and urban operation, having as device the social medicine and the Sanitary Education as a guide for social and individual health; (b) alliance between education and health, having as effect the health education practices that, in turn, use techniques of education and popular participation to promote personal hygiene as an object of public health and safety; and (c) the government of self for the benefit of the species, that is, the strategy of maintaining and improving individual habits and manners as a promis e of happiness, not of each one, but of this artificial soul, the city.

About this composition of forces, it was possible to show, as a technique of subjectification, this "popular pedagogy of personal hygiene" (Corbin, 1987, p. 98), in which the townsmen stop experiencing the standards as an imposition to recognize themselves in them. Indeed, hygienic habits promoted by social medicine and by sanitary education encourage their spread in popular classes, promising to the life of the city health and longevity. It is aroused, therefore, a tactical complement to the strategy of ordering city habits and manners. The production of a "sanitary awareness", no longer for compliance to the rules, but for the desire for a healthy body and society. Only this way the citizen would be mobilized to change their habits according to the precepts of hygiene in adherence to a proposed public health.

\section{Sources}

Godoy, A. (1923). Algumas ideas sobre a remodelação das cidades. Annaes do Primeiro Congresso Brasileiro de Hygiene. Biblioteca Oswaldo Cruz/Fundação Oswaldo Cruz (Fiocruz), Rio de Janeiro.

Machado, A. (1918). Problemas municipaes. São Paulo: [s.n.].

Pinto, A. J. (1901). Projeto de Remoção do Lixo. Arquivo Geral da Cidade do Rio de Janeiro, Notação: 31.3.13. Rio de Janeiro.

VII Congresso Brasileiro de Higiene. (1943). Anais do VII Congresso Brasileiro de Higiene. São Paulo: Typografia do Departamento de Investigações.

\section{References}

Baptista, L. A. (1999). A cidade dos sábios: reflexões sobre a dinâmica social nas grandes cidades. São Paulo: Summus.

Castro, E. (2009). Vocabulário de Foucault. Um percurso pelos seus temas, conceitos e autores (I. M. Xavier, Trad.; A. Veiga-Neto \& W. O. Kohan, Rev. Técn.). Belo Horizonte: Autêntica Editora.

Corbin, A. (1987). Saberes e odores: o olfato e o imaginário social nos séculos XVIII e XIX. (L. Watanabe, Trad.). São Paulo: Companhia das Letras. .

Costa, J. F. (2004). Ordem médica e norma familiar ( $5^{\mathrm{a}} \mathrm{ed}$.). Rio de Janeiro: Edições Graal.

David, H. M. S. L. \& ACIOLI, S. (2010). Mudanças na formação e no trabalho de enfermagem: uma perspectiva de educação popular e de saúde. Revista Brasileira de Enfermagem, 63(1), 127-131.

Foucault, M. (1995). O sujeito e o poder. In H. L. Dreyfus \& P. Rabinow, Michel Foucault, uma trajetória filosófica: para além do estruturalismo e da hermenêutica (pp. 231-249). Rio de Janeiro: Forense-Universitária.

Foucault, M. (2004a). Nietzsche, a genealogia e a história. In M. Foucault, Microfisica do poder (R. Machado, Trad. Org., pp. 15-37). Rio de Janeiro: Edições Graal.

Foucault, M. (2004b). O nascimento da medicina social. In M. Foucault, Microfísica do poder (R. Machado, Trad. Org., pp. 79-98). Rio de Janeiro: Edições Graal.

Foucault, M. (2008a). O nascimento da clínica (R. Machado, Trad.). Rio de Janeiro: Forense-Universitária.

Foucault, M. (2008b). Segurança, território, população: curso dado no Collège de France 1977-1978 (E. Brandão, Trad.). São Paulo: Martins Fontes.

Hobbes, T. (1997). Leviatã ou matéria, forma e poder de um estado eclesiástico e civil (J. P. Monteiro \& M. B. N. Silva, Trads., Coleção Os Pensadores). São Paulo: Nova Cultural, 1997

Renovato, R. D. \& Bagnato, M. H. S. (2011). A educação sanitária nos centros de saúde de São Paulo (1925-1930). História da Enfermagem. Revista Eletrônica, 2(2), 61-72. 
Sennet, R. (1997). Carne e pedra (M. A. Reis, Trad.). Rio de Janeiro: Record.

Souza, A. D. C. (2007). Tigres: "Tristes Operários do Labor Imundo". Dissertação de Mestrado, Programa de PósGraduação em Educação Ambiental, Universidade Federal Fluminense, Niterói, RJ.

Received in: 2012-09-29

Revised in: 2013-01-14

Accepted in: 2013-06-05

Ricardo Abussafy de Souza is a doctor in Psychology at "Julio de Mesquita Filho" São Paulo State University College of Letters and Science - Assis Campus (UNESP/ FCL - Assis, SP). Address: Rua Heitor Penteado, 1707, apto. 72, Sumarezinho. São Paulo/SP, Brasil. CEP 05437-001. Email: abussafy@gmail.com
Sonia Aparecida Moreira França is a Professor of the Graduate Program in Psychology at "Julio de Mesquita Filho" São Paulo State University - College of Letters and Science - Assis Campus (UNESP/FCL - Assis, SP). Email: soniamfranca@uol.com.br

\section{How to cite this article:}

Souza, R. A. \& França, S. A. M. (2013). Social medicine in Brazil: an alliance between sanitary education and popular pedagogy. Psicologia \& Sociedade, 25(n. spe.), 70-79. 